\title{
COVID-19 reinfection - An enigmatic public health threat
}

\author{
Karthikeyan P. Iyengar', Vijay Kumar Jain ${ }^{2}$, Pranav Ish ${ }^{3}$ \\ ${ }^{1}$ Trauma and Orthopaedic Surgeon, Southport and Ormskirk NHS Trust, Southport, UK; ${ }^{2}$ Department of Orthopaedics, \\ Atal Bihari Vajpayee Institute of Medical Sciences, Dr Ram Manohar Lohia Hospital, New Delhi, India; ${ }^{3}$ Department of \\ Pulmonary, Critical Care and Sleep Medicine, Vardhman Mahavir Medical College and Safdarjung Hospital, New Delhi, \\ India
}

\section{To The Editor,}

The COVID-19 pandemic has been consistently on the rise across the globe. The recovered patients getting long-term sequelae, especially lung fibrosis and residual neurological deficits, is an area of concern. Another extremely important conundrum is the risk of re-infection. It has been recently documented from Hong Kong [1] and puts an unpleasant question mark on long term immunity, sampling technique standardization, viral mutation and efficacy of herd immunity. There are definitions for COVID -19 infection and its severity [2], but unfortunately none for re-infection.

Microbiologically, recurrent tuberculosis is classified as relapse if the same genotyped organism is isolated again and reinfection if there is a new strain [3]. Similar definition can be useful for COVID-19. However, in view of paucity of evidence and literature, no guidelines mention or discuss this pertinent issue.

The multiple case series, reported from China, document cases which turned Polymerase chain reaction (PCR) negative in

\section{Correspondence: Dr Pranav Ish, Department of Pulmonary, Critical Care and Sleep Medicine, Vardhman Mahavir Medical College and Safdarjung Hospital, New Delhi, India. \\ E-mail: pranavish2512@gmail.com \\ Conflict of interest: The authors declare that they have no competing interests, and all authors confirm accuracy.}

Contributions: All the 3 authors contributed to substantial contributions to the conception or design of the work; or the acquisition, analysis, or interpretation of data for the work; drafting the work or revising it critically for important intellectual content; final approval of the version to be published. All the authors have read and approved the final version of the manuscript and agreed to be accountable for all aspects of the work in ensuring that questions related to the accuracy or integrity of any part of the work are appropriately investigated and resolved

Key words: COVID-19; reinfection; herd immunity.

Received for publication: 3 September 2020

Accepted for publication: 30 October 2020.

${ }^{\circ}$ Copyright: the Author(s), 2020

Licensee PAGEPress, Italy

Monaldi Archives for Chest Disease 2020; 90:1596

doi: 10.4081/monaldi.2020.1596

This article is distributed under the terms of the Creative Commons Attribution Noncommercial License (by-nc 4.0) which permits any noncommercial use, distribution, and reproduction in any medium, provided the original author(s) and source are credited. nasopharyngeal swab at discharge with resolution of symptoms and subsequently returned PCR positive in follow up swab tests [4-9]. The patients were mild to moderate cases returning PCR positive ranging from day 7 to even up to 4 weeks after discharge. There were multiple speculations and possible explanations putfalse negative PCR at the time of discharge due to improper sampling, transport, processing, low viral load or laboratory error. The repeat positivity could be attributed to false positive results due to contamination in sampling or in the lab, residual viral RNA, or cross reaction with other viruses. As there was no viral culture and genetic analysis performed, this resurgence could have been reinfection, relapse or a mere lab error. These results signified the variable presence of viral load, the risk of reinfection and the need for isolation for prolonged periods to prevent spread of infection.

The Korean database of resurgence of PCR positivity was also within a week of recovery. This was also postulated to be a reactivation of the virus rather than reinfection [10]. The recent Hong Kong reported case, however, has a time gap of over 4 months, a laboratory proven different genotype resembling the European virus and the patient was also returning from Europe. Thus, it was most likely a re-infection. This case highlights the importance of immunity, its type and most importantly, its duration of efficacy. Even though CDC suggests that antibody response to COVID-19 lasts for 2 to 3 months, there is variability in duration among various individuals. Besides, eventually the antibody response has been found to wade. This leads to the risk of reinfection, especially from a different strain of the virus. Thus, the concept of generating herd immunity seems practically difficult to achieve. Similar thoughts were shared in a recent letter [11]. Thus, in the absence of an effective vaccine, there is very little we can do to prevent the spread of COVID-19 [12]. Personal protective equipment (PPE), physical distancing and lockdown are effective strategies to delay and prevent precipitous rise of cases. Attempts to allow relaxation in the above with a hope of herd immunity has already shown to be counter-productive in developed nations like the United Kingdom.

The implication of recent reports of positive Real-time reverse transcriptase- polymerase chain reaction (RT-PCR) test after a variable period of negativity suggests that at least a proportion of recovered patients may still be virus carriers [2]. The inference that can be drawn from these case reports and cohort studies albeit small; suggest a need to revisit current criteria for hospital discharge of patients, discontinuation of quarantine period and return to work especially of doctors and health care workers. National guidelines in India recommend discharge of a patient 10 days after symptom onset with 7 days of further home isolation. There is no PCR test recommended on discharge as it is believed that patients often become non-infectious. In severe COVID-19 and immunocompromised patients, the guidelines recommend to discharge the 
patients only after the patient turns RT-PCR negative. This is because such patients have high viral loads and have been found to have prolonged viral positivity [2].

We feel with the evident uncertainty public health agencies may need to re-evaluate the current criteria for discharge of patients from surveillance and monitoring to reduce the risk of transmission of COVID-19

- Additional confirmatory tests or tests to rule out persistent carriage of virus should be undertaken prior to discontinuation of patient surveillance including repeating viral RT-PCR after a prolonged interval, undertaking antibody testing and or use of next-generation sequencing may be necessary to assure the virus has cleared [7].

- Recognition of risk of reactivation and reinfection needs to be borne in mind evaluating patients recovering from the disease and any concurrent spikes of infection in the community.

- Epidemiological serological surveys, longitudinal and long cohort studies need to be undertaken as a matter of urgency to better understand the course of COVID-19 and prevent a 'second wave' in the winter.

- Reinfection is a possibility. Thus, recovery from COVID-19 infection or even presence of antibody titre should not give a false sense of security which leads to breach in physical distancing, PPE and sanitation practices.

- Vaccine development research will face reinfection as a hindrance and challenge. Thus, genotyping all suspected reinfections and subsequent modifications or novel vaccines may be required in the future similar to a new annual influenza vaccine on the basis of prevalent strains.

\section{References}

1. Times of India [Internet]. Coronavirus: First case of COVID19 reinfection confirmed in Hong Kong; here is what it means. 2020. Last accessed on: 28 August 2020. Available from: https://timesofindia.indiatimes.com/life-style/health- fitness/health-news/coronavirus-first-case-of-covid-19-reinfection-confirmed-in-hong-kong-here-is-what-it-means/photostory $/ 77735865 . \mathrm{cms}$.

2. Government of India, Ministry of Health and Family Welfare. Clinical management protocol: COVID-19. Last accessed on: 28 August 2020. Available from: https://www.mohfw.gov.in/pdf/ ClinicalManagementProtocolforCOVID19.pdf

3. Zong Z, Huo F, Shi J, et al. Relapse versus reinfection of recurrent tuberculosis patients in a national tuberculosis specialized hospital in Beijing, China. Front Microbiol 2018;9:1858.

4. Xing Y, Mo P, Xiao Y, et al. Post-discharge surveillance and positive virus detection in two medical staff recovered from coronavirus disease 2019 (COVID-19), China, January to February 2020. Euro Surveill 2020;25:2000191.

5. Lan L, Xu D, Ye G, et al. Positive RT-PCR test results in patients recovered from COVID-19. JAMA 2020;323:1502-3.

6. Yuan J, Kou S, Liang Y, et al. PCR Assays turned positive in 25 discharged COVID-19 patients. Clin Infect Dis 2020:ciaa398. doi: 10.1093/cid/ciaa398

7. Chen D, Xu W, Lei Z, et al. Recurrence of positive SARSCoV-2 RNA in COVID-19: A case report. Int J Infect Dis 2020; 93:297-9.

8. Wang $\mathrm{X}, \mathrm{Xu} \mathrm{H}$, Jiang $\mathrm{H}$, et al. The clinical features and outcomes of discharged coronavirus disease 2019 patients: A prospective cohort study. QJM 2020;hcaa178. doi: 10.1093/ qjmed/hcaa178

9. Yang JR, Deng DT, Wu N, et al. Persistent viral RNA positivity during the recovery period of a patient with SARS-CoV-2 infection. J Med Virol 2020. doi: 10.1002/jmv.2594

10. Reuters [Internet]. South Korea reports more recovered coronavirus patients testing positive again. Last accessed on: 28 August 2020. Available from: https://www.reuters.com/article/us-health-coronavirus-southkorea/south-korea-reportsmore-recovered-coronavirus-patients-testing-positive-againidUSKCN21V0JQ

11. Ramachandran R. COVID-19-a very visible pandemic. Lancet 2020;396:e13-4.

12. Giesecke J. The invisible pandemic. Lancet 2020;395:e98. 